See Article page 334 .

\section{Commentary: The very real generation gap: Times are a-changing}

\author{
Susan D. Moffatt-Bruce, MD, PhD, FACS, FRCSC, ${ }^{\text {a }}$ \\ and Peter Kneuertz, MD $^{\mathrm{b}}$
}

One cannot help but think to the song writer Bob Dylan and his 1964 release of "The Times They Are a-Changin"" (Figure 1) when we read the outstanding article of Luc and colleagues, ${ }^{1}$ who instead of simply describing changes in our profession, actually gives us solutions for thoughtful and meaningful change. As this article clearly articulates, Millennial cardiothoracic surgery residents are training under unprecedented challenges. The imposed work-hour restriction is one of the most significant differences in our opinion. ${ }^{2,3}$ These restrictions, put in place originally to improve the quality of care, actually have not yet impacted patient safety. ${ }^{2}$ Interestingly, allowing flexibility rather than purely restricting duty-hours has not adversely affected hospital finances or patient experience. ${ }^{3}$ Work-hour restrictions have, however, affected resident autonomy. These challenges must be compensated by maximizing the quality, rather than the quantity, of hours, which further emphasizing the need for us to have effective teaching strategies tailored to our current generation.

The second, important influence that our Millennial residents are enduring is public reporting in a value-based care era. As outcomes are increasingly transparent at the surgeon level, faculty have become warier and even restrictive in what the residents are allowed to do. ${ }^{4}$ Our responsibility as teachers, however, must remain to ensure residents learn what they need for independent practice. Building trusted

\footnotetext{
From the ${ }^{\text {a }}$ The Royal College of Physicians and Surgeons of Canada, Ottawa, Ontario, Canada; and ${ }^{\mathrm{b}}$ Department of Surgery, The Ohio State University, Columbus, Ohio. Disclosures: The authors reported no conflicts of interest.

The Journal policy requires editors and reviewers to disclose conflicts of interest and to decline handling or reviewing manuscripts for which they may have a conflict of interest. The editors and reviewers of this article have no conflicts of interest.

Received for publication April 10, 2020; accepted for publication April 13, 2020; available ahead of print April 21, 2020.

Address for reprints: Susan D. Moffatt-Bruce, MD, PhD, FACS, FRCSC, The Royal College of Physicians and Surgeons of Canada, 774 Echo Dr, Ottawa, Ontario K1S 5N8, Canada (E-mail: Smoffattbruce@royalcollege.ca).

J Thorac Cardiovasc Surg 2021;162:343-4

0022-5223/\$36.00

Copyright (c) 2020 by The American Association for Thoracic Surgery

https://doi.org/10.1016/j.jtcvs.2020.04.045
}

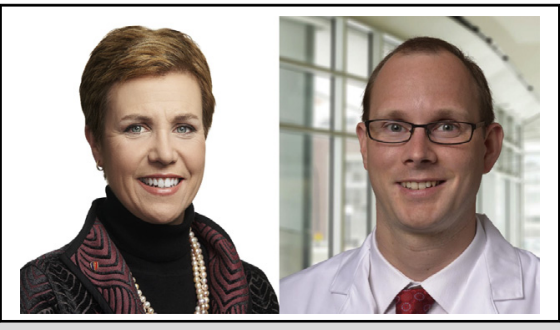

Susan D. Moffatt-Bruce, MD, PhD, FACS, FRCSC (left), and Peter Kneuertz, MD (right)

\section{CENTRAL MESSAGE \\ Millennial leaners are our future. They are innovative, technology savvy, and team-based. We, as teachers, must change so to elevate this generation.}

relationships and accurately evaluating resident operative competencies can effectively entrust responsibility while remaining in control of our outcomes. ${ }^{5}$

So, to embrace Millennials' dedication and support their uniqueness, we first need to understand what makes a Millennial learner unique. Luc and colleagues first point to their use of technology, which opens the door for virtual learning and networking regardless of geography. ${ }^{6}$ Their use of Twitter and online learning is to be commended, as evident in the current coronavirus disease 2019 (COVID-19) crisis. $^{7}$ Using social media, residents, faculty, and staff have been successful in sharing best practices and lessons learned from treating patients and protecting ourselves.

Another important differentiator of Millennial residents is the fact that they thrive on real-time objective performance data and feedback. ${ }^{1}$ The Competency-By-Design framework in Canada and the Milestone project in the United States are both designed to train our residents to competency rather than time. ${ }^{8,9}$ However, again it is on us, the teachers, to inform ourselves on how to best train to competency, as most of us trained to time.

Lastly, Millennial learners approach their educational environments so to work in teams. Inherent to the Millennial expectations of what defines their teams is diversity and inclusion. In cardiothoracic surgery, this has not always been our forte. ${ }^{10}$ However, increased attention to diversity, physician wellbeing, and inclusive culture and leadership, we are gradually improving. We must lead by example and accept what our Millennial trainees assume 
"Come mothers and fathers, Throughout the land

And don't criticize

What you can't understand

Your sons and your daughters

Are beyond your command

Your old road is

Rapidly agin'

Please get out of the new one

If you can't lend your hand

For the time they are a-changin"”

\section{- Bob Dylan}

FIGURE 1. Bob Dylan, “The Times They Are a-Changin"” lyrics. (C1963, 1964 by Warner Bros Inc; renewed 1991, 1992 by Special Rider Music.

is the acceptable as the only standard. As Bob Dylan prophesized, changes to traditional, unacceptable standards would eventually be replaced with tolerance and equality. In that spirit, we as teachers have an opportunity to develop and elevate this generation within our profession if we take their advice.

\section{References}

1. Luc JGY, Antonoff MB, Vaporciyan AA, Yanagawa B. Surgeon teachers and millennial learners: bridging the generation gap. J Thorac Cardiovasc Surg. 2021;162:334-41

2. Silber JH, Bellini LM, Shea JA, Desai SV, Dinges DF, Basner M, et al. Patient safety outcomes under flexible and standard resident duty-hour rules. $N$ Engl J Med. 2019;380:905-14.

3. Rajaram R, Saadat L, Chung J, Dahike A, Yang AD, Odell DD, et al. Impact of the 2011 ACGME resident duty hour reform on hospital patient experience and processes-of-care. BMJ Qual Saf. 2016;25:962-70.

4. Moffatt-Bruce SD, Nguyen MC, Fann JI, Westaby S. Our new reality of public reporting: shame rather than blame? Ann Thorac Surg. 2016;101:1255-61.

5. Moffatt-Bruce SD, Ross P, Williams TE. American Board of Thoracic Surgery examination: fever graduates, more failures. J Thorac Cardiovasc Surg. 2014; 147:1464-9.

6. Antonoff MB, Verrier ED, Allen MS, Aloia L, Baker C, Fann JI, et al. Impact of Moodle-based online curriculum on thoracic surgery in-training examination scores. Ann Thorac Surg. 2016;102:1381-6.

7. Chan AKM, Nickson CP, Rudolph JW, Lee A, Joynt GM. Social media for rapid knowledge dissemination: early experience from the COVID-19 pandemic. Anaesthesia. March 30, 2020 [Epub ahead of print].

8. Noly PE, Rubens FD, Ouzounian M, Quantz M, Shao-Hua W, Pelletier M, et al. Cardiac surgery training in Canada: current state and future perspectives. $J$ Thorac Cardiovasc Surg. 2017;154:998-1005.

9. Mitzman B, Beller JP, Edgar J. Thoracic surgery milestones 2.0: rationale and revision. J Thorac Cardiovasc Surg. March 31, 2020 [Epub ahead of print].

10. Backhus LM, Fann BE, Hui DS, Cooke DT, Berfield KS, Moffatt-Bruce SD. Culture of safety and gender inclusion in cardiothoracic surgery. Ann Thorac Surg. 2018;106:951-8. 